\title{
Effect of feeding by Metadelphax propinqua (Fieber)(Homoptera, Delphacidae) on barley
}

\author{
Mikko RaAtikainen, Terttu RaAtikainen and ARJa Vasarainen
}

RaAtikainen, M., RaAtikainen, T. \& Vasarainen, A. 1994. Effect of feeding by Metadelphax propinqua (Fieber) (Homoptera, Delphacidae) on barley. Agricultural Science Finland 3: 513-517. (University of Jyväskylä, Department of Biological and Environmental Science, P. O. Box 35, FIN-40351 Jyväskylä, Finland and Agricultural Research Centre of Finland, Institute of Plant Protection, FIN-31600 Jokioinen, Finland.)

The effect of feeding by the Turkish Metadelphax propinqua on barley was investigated in Finland. The number of $M$. propinqua nymphs and the length of their feeding period on barley did not have any major effects on the barley plants. $M$. propinqua males had a greater effect on the properties of barley than did the nymphs. The effect of $M$. propinqua females on the barley was much greater than that of either the nymphs or males. Their number and the length of feeding time lowered the length and weight of plants, the number of grains, the grain yield and the 1000-grain weight.

Key words: feeding period, female, male, nymph

\section{Introduction}

In 1969-1970 we investigated cereal diseases transmitted or caused by aphids and leafhoppers in Turkey. Our interest focused on the biology of Metadelphax propinqua (Fieber) (Homoptera, Delphacidae), also (RAATIKAINEN and VASARAINEN 1990), a planthopper widely distributed in the Palaearctic and Nearctic region (MetCALF 1943). According to Dlabola (1957), it is also common in Turkey. We were primarily concerned with the damage it does to barley.

\section{Material and methods}

We started with an investigation of the ecology of $M$. propinqua at Bornova in western Turkey and continued with trials at Tikkurila in Finland. The planthoppers were collected from a field at
Bornova. The tests were conducted from September 1971 to March 1972 in a glasshouse at a temperature of $20-25^{\circ} \mathrm{C}$. The test plant was barley (cultivar Tammi). The plants were sown in $43 \times 25 \times 12-\mathrm{cm}$ wooden boxes lined with polyethylene film. The bottoms of the boxes were perforated to allow drainage. Seeds of test plants were sown in six parallel rows, four seeds to each row, at equal distances from one another and at a depth of $3 \mathrm{~cm}$. During test feeding periods each planthopper was caged with one seedling under a cylinder of PVC plate, $3 \mathrm{~cm}$ in diameter and $25 \mathrm{~cm}$ tall; the upper end was covered with gauze. There were also two ventilation openings near the bottom. Control plants were caged in the same manner.

The number of planthoppers on one plant in the rearing box was $0,1,2$ or 4 and the length of the feeding period was 4,8 or 16 days. The trials were made with nymphs, males and females. The 
Table 1. Effect of feeding by Metadelphax propinqua nymphs on barley.

\begin{tabular}{|c|c|c|c|c|c|c|c|c|c|c|}
\hline \multirow[t]{2}{*}{ Property measured } & \multicolumn{5}{|c|}{ No. of planthoppers/plant } & \multicolumn{4}{|c|}{ Feeding period, days } & \multirow{2}{*}{$\begin{array}{c}\text { Planthopper } \\
\text { x feeding } \\
\text { F }\end{array}$} \\
\hline & 0 & 1 & 2 & 4 & $\mathrm{~F}$ & 4 & 8 & 16 & $\mathrm{~F}$ & \\
\hline $\begin{array}{l}\text { Length of plant after } \\
22 \text { days, cm }\end{array}$ & 19.9 & 19.6 & 19.7 & 17.8 & 1.89 & 19.5 & 18.7 & 19.5 & 0.53 & $3.56^{* *}$ \\
\hline $\begin{array}{l}\text { Total length of mature } \\
\text { plant, } \mathrm{cm}\end{array}$ & 64.7 & 60.0 & 58.2 & 56.7 & 1.91 & 60.9 & 60.6 & 58.1 & 0.51 & \\
\hline No. of shoots & 2.1 & 2.2 & 2.1 & 2.2 & 0.06 & 2.2 & 2.1 & 2.2 & 0.11 & \\
\hline Dry weight of plant, mg & 1489.9 & 1364.0 & 1274.2 & 1147.1 & $4.15^{* *}$ & 1439.1 & 1347.1 & 1170.2 & $4.94 * *$ & $2.27 * *$ \\
\hline $\begin{array}{l}\text { No. of grains on } \\
\text { main shoot }\end{array}$ & 11.1 & 9.3 & 9.1 & 10.0 & 0.73 & 10.1 & 10.0 & 9.5 & 0.12 & \\
\hline $\begin{array}{l}\text { No. of grains on } \\
\text { secondary shoots }\end{array}$ & 10.2 & 10.7 & 9.3 & 7.6 & 0.80 & 10.3 & 9.8 & 8.3 & 0.61 & \\
\hline No. of grains on plant & 21.3 & 20.0 & 18.4 & 17.6 & 2.14 & 20.4 & 19.8 & 17.8 & 1.92 & \\
\hline $\begin{array}{l}\text { Grain yield per main } \\
\text { shoot, mg }\end{array}$ & 398.8 & 313.5 & 313.2 & 333.8 & 1.26 & 348.8 & 345.6 & 325.0 & 0.17 & \\
\hline $\begin{array}{l}\text { Grain yield per } \\
\text { secondary shoots, mg }\end{array}$ & 298.3 & 326.6 & 275.3 & 225.7 & 0.82 & 315.9 & 219.8 & 236.8 & 0.99 & \\
\hline Grain yield per plant, $\mathrm{mg}$ & 697.1 & 640.1 & 588.5 & 559.4 & $2.86^{*}$ & 664.6 & 637.4 & 561.8 & 2.95 & $2.43^{*}$ \\
\hline $\begin{array}{l}1000 \text {-grain weight on } \\
\text { main shoot, g }\end{array}$ & 32.0 & 24.6 & 26.5 & 24.5 & $2.65^{*}$ & 27.0 & 27.6 & 26.1 & 0.15 & \\
\hline $\begin{array}{l}\text { 1000-grain weight on } \\
\text { secondary shoots, g }\end{array}$ & 15.7 & 18.7 & 15.3 & 14.9 & 0.69 & 16.0 & 15.7 & 16.8 & 0.09 & \\
\hline
\end{tabular}

test plants were six days old at the beginning of the trials. The length of the day was 16-19 h. The plant properties measured are listed in Tables 1-3.

The statistical method used was analysis of variance, and statistical significance is indicated by asterisks as follows: $* * *=\mathrm{P}<0.001, * *=\mathrm{P}$ $<0.01$ and $*=\mathrm{P}<0.05$.

\section{Results}

The number of $M$. propinqua nymphs and the length of their feeding period (time of stay) on barley did not have any major effect on the plant properties measured (Table 1). The most important change occurred in the dry weight of the plants, which decreased significantly due to the effect of both the number of nymphs and the length of their feeding period. The combined ef- fect of the number of nymphs and the length of their feeding period on the length of barley plants was significant 22 days after sowing. The number of nymphs lowered the grain weight of whole plants and the 1000-grain weight of the main shoot almost significantly.

M. propinqua males had a more marked effect on the properties of barley than did the nymphs (Table 2). The greater the number of males and the longer the time that had passed since feeding, the less the barley grew in length. Further, the greater the number of males on a plant, and the longer the feeding period, the more the weight of the plant decreased. Feeding led to a decrease in the number and weight of grains of the whole plant and secondary shoots.

The effect of $M$. propinqua females on the properties of barley was much greater than that of either males or nymphs (Table 3 ). The number of females and the length of their feeding period 
Table 2. Effect of feeding by Metadelphax propinqua males on barley.

\begin{tabular}{|c|c|c|c|c|c|c|c|c|c|c|}
\hline \multirow[t]{2}{*}{ Property measured } & \multicolumn{5}{|c|}{ No. of planthoppers/plant } & \multicolumn{4}{|c|}{ Feeding period, days } & \multirow{2}{*}{$\begin{array}{c}\text { Planthopper } \\
\text { x feeding } \\
\text { F }\end{array}$} \\
\hline & 0 & 1 & 2 & 4 & $\mathrm{~F}$ & 4 & 8 & 16 & $\mathrm{~F}$ & \\
\hline \multicolumn{11}{|l|}{ Length of plant after } \\
\hline 22 days, $\mathrm{cm}$ & 19.2 & 19.0 & 17.3 & 16.4 & $5.12^{* *}$ & 18.3 & 17.0 & 18.6 & 2.82 & \\
\hline $\begin{array}{l}\text { Length of plant after } \\
30 \text { days, cm }\end{array}$ & 29.7 & 32.2 & 29.3 & 29.0 & 1.33 & 310 & 30.0 & 29.1 & 0.75 & \\
\hline Length of plant after & & & & & & & & & & \\
\hline 39 days, $\mathrm{cm}$ & 50.8 & 51.5 & 48.5 & 47.3 & 1.24 & 50.6 & 49.9 & 47.8 & 1.07 & \\
\hline Length of plant after & & & & & & & & & & \\
\hline Length of mature plant & & & & & & 政 & (5) & Ne. & 0.00 & \\
\hline $\begin{array}{l}\text { (tip of uppermost sheath } \\
\text { to base of panicle), } \mathrm{cm}\end{array}$ & 59.2 & 56.4 & 52.6 & 52.5 & $6.77 * * *$ & 55.2 & 56.7 & 53.6 & 2.03 & \\
\hline $\begin{array}{l}\text { Total length of mature } \\
\text { plant, } \mathrm{cm}\end{array}$ & 68.7 & 65.6 & 60.4 & 61.1 & $5.52 * * *$ & 63.6 & 66.5 & 61.7 & 2.85 & \\
\hline No. of shoots & 1.4 & 1.7 & 1.8 & 1.8 & $3.10^{*}$ & 1.7 & 1.5 & 1.7 & 1.75 & \\
\hline $\begin{array}{l}\text { Dry weight of main } \\
\text { shoot, mg }\end{array}$ & 1129.3 & 845.7 & 744.9 & 692.8 & $10.57 * * *$ & 895.8 & 918.0 & 745.8 & $3.23 *$ & \\
\hline $\begin{array}{l}\text { Dry weight of secondary } \\
\text { shoots, mg }\end{array}$ & 241.3 & 359.8 & 371.0 & 260.6 & 1.01 & 470.5 & 227.3 & 226.8 & $5.98 * *$ & \\
\hline Dry weight of plant, mg & 1370.7 & 1205.5 & 1115.9 & 953.4 & $6.41 * * *$ & 1366.3 & 1145.3 & 972.6 & $10.96^{* * *}$ & \\
\hline $\begin{array}{l}\text { No. of grains on } \\
\text { main shoot }\end{array}$ & 10.5 & 8.8 & 7.6 & 7.0 & 1.77 & 8.3 & 9.9 & 7.2 & 1.79 & \\
\hline $\begin{array}{l}\text { No. of grains on } \\
\text { secondary shoots }\end{array}$ & 4.3 & 7.2 & 7.2 & 5.2 & 1.05 & 9.3 & 4.8 & 3.9 & $5.50^{* *}$ & \\
\hline No. of grains on plant & 14.8 & 16.0 & 14.8 & 12.2 & 1.21 & 17.6 & 14.6 & 11.1 & $6.80^{* *}$ & \\
\hline $\begin{array}{l}\text { Grain yield per main } \\
\text { shoot, mg }\end{array}$ & 391.3 & 318.5 & 275.1 & 249.9 & 2.32 & 329.8 & 341.6 & 2544.7 & 1.79 & \\
\hline $\begin{array}{l}\text { Grain yield per secondary } \\
\text { shoots, mg }\end{array}$ & 91.4 & 165.2 & 152.7 & 107.5 & 1.29 & 206.9 & 102.1 & 78.5 & $6.42 * *$ & \\
\hline Grain yield per plant, mg & 482.8 & 483.7 & 427.8 & 357.4 & 2.16 & 536.8 & 443.8 & 333.2 & $8.38 * * *$ & \\
\hline Age of main shoot, days & 95.9 & 93.6 & 95.4 & 93.9 & 0.34 & 94.3 & 94.4 & 95.4 & 0.14 & \\
\hline $\begin{array}{l}\text { 1000-grain weight on } \\
\text { main shoot, } g\end{array}$ & 29.9 & 33.1 & 27.5 & 28.4 & 0.89 & 30.6 & 30.5 & 28.0 & 0.41 & \\
\hline $\begin{array}{l}\text { 1000-grain weight on } \\
\text { secondary shoot, g }\end{array}$ & 5.7 & 10.0 & 9.3 & 8.4 & 1.27 & 10.7 & 6.1 & 8.2 & 2.51 & \\
\hline
\end{tabular}

usually lowered very significantly or significantly the length and weight of plants, the number of grains, the grain yield and the 1000-grain weight. The effect on growth was most striking at the end of the feeding period, but thereafter the plant seeded and gradually recovered.

\section{Discussion}

Our earlier studies (BREMER and RAATIKAINEN 1975 ) indicated that the planthopper individuals we investigated did not transmit viruses.

$M$. propinqua is a small planthopper that dam- 
Table 3. Effect of feeding by Metadelphax propinqua females on barley.

\begin{tabular}{|c|c|c|c|c|c|c|c|c|c|c|}
\hline \multirow[t]{2}{*}{ Property measured } & \multicolumn{5}{|c|}{ No. of planthoppers/plant } & \multicolumn{4}{|c|}{ Feeding period, days } & \multirow{2}{*}{$\begin{array}{l}\text { Planthopper } \\
\text { x feeding } \\
\text { F }\end{array}$} \\
\hline & 0 & 1 & 2 & 4 & $\mathrm{~F}$ & 4 & 8 & 16 & $\mathrm{~F}$ & \\
\hline $\begin{array}{l}\text { Length of plant after } \\
22 \text { days, } \mathrm{cm}\end{array}$ & 19.4 & 13.5 & 11.8 & 8.2 & $85.42^{* * *}$ & 16.0 & 13.4 & 10.3 & $43.04 * * *$ & $8.10^{* * *}$ \\
\hline $\begin{array}{l}\text { Length of plant after } \\
30 \text { days, } \mathrm{cm}\end{array}$ & 30.2 & 23.4 & 21.4 & 14.3 & $39.92^{* * *}$ & 26.9 & 23.8 & 16.4 & $35.89^{* * *}$ & $4.31^{* * *}$ \\
\hline $\begin{array}{l}\text { Length of plant after } \\
39 \text { days, cm }\end{array}$ & 50.7 & 41.1 & 37.2 & 25.7 & $38.96^{* * *}$ & 46.1 & 41.5 & 28.4 & $41.06^{* * *}$ & $2.87^{*}$ \\
\hline $\begin{array}{l}\text { Length of plant after } \\
46 \text { days, } \mathrm{cm}\end{array}$ & 56.8 & 46.7 & 42.7 & 31.2 & $36.36 * * *$ & 52.1 & 47.0 & 33.9 & $38.18^{* * *}$ & $2.49^{*}$ \\
\hline $\begin{array}{l}\text { Length of mature plant } \\
\text { (tip of uppermost sheath } \\
\text { to base of panicle), } \mathrm{cm}\end{array}$ & 58.4 & 50.2 & 46.7 & 38.4 & $24.67^{* * *}$ & 54.6 & 50.8 & 39.8 & $28.30 * * *$ & \\
\hline $\begin{array}{l}\text { Total length of mature } \\
\text { plant, cm }\end{array}$ & 67.9 & 58.0 & 54.9 & 45.4 & $20.07 * * *$ & 64.2 & 59.6 & 45.8 & $28.33 * * *$ & \\
\hline No. of shoots & 1.8 & 1.3 & 1.3 & 1.2 & $7.12^{* * *}$ & 1.6 & 1.3 & 1.3 & $4.96 * *$ & \\
\hline $\begin{array}{l}\text { Dry weight of main } \\
\text { shoot, mg }\end{array}$ & 1081.9 & 766.4 & 605.1 & 433.7 & $26.06 * * *$ & 918.6 & 760.4 & 486.4 & $21.83^{* * *}$ & \\
\hline $\begin{array}{l}\text { Dry weight of secondary } \\
\text { shoots, mg }\end{array}$ & 586.8 & 149.1 & 110.7 & 118.6 & $8.82^{* * *}$ & 403.8 & 179.2 & 141.0 & $4.44^{*}$ & \\
\hline Dry weight of plant, mg & 1668.8 & 915.5 & 715.8 & 552.3 & $34.38 * * *$ & 1322.3 & 939.6 & 627.4 & $22.82 * * *$ & \\
\hline $\begin{array}{l}\text { No. of grains on } \\
\text { main shoot }\end{array}$ & 9.3 & 8.1 & 5.8 & 4.8 & $4.38 * *$ & 8.3 & 7.5 & 5.2 & $3.66^{*}$ & \\
\hline $\begin{array}{l}\text { No. of grains on } \\
\text { secondary shoots }\end{array}$ & 10.1 & 2.7 & 2.3 & 1.7 & $8.82 * * *$ & 6.6 & 2.9 & 3.0 & $3.39 *$ & \\
\hline No. of grains on plant & 19.3 & 10.8 & 8.1 & 6.5 & $17.19 * * *$ & 14.9 & 10.4 & 8.2 & $8.24 * * *$ & \\
\hline $\begin{array}{l}\text { Grain yield per main } \\
\text { shoot, mg }\end{array}$ & 337.7 & 278.6 & 187.3 & 129.3 & $8.64 * * *$ & 290.4 & 249.3 & 159.9 & $5.95^{* *}$ & \\
\hline $\begin{array}{l}\text { Grain yield per secondary } \\
\text { shoots, mg }\end{array}$ & 248.3 & 54.0 & 48.0 & 48.6 & $8.10^{* * *}$ & 167.2 & 75.1 & 56.9 & $3.84^{*}$ & \\
\hline Grain yield per plant, mg & 586.0 & 332.6 & 235.3 & 177.8 & $21.04 * * *$ & 457.6 & 324.4 & 216.8 & $12.55^{* * *}$ & \\
\hline Age of main shoot, days & 98.4 & 101.5 & 101.8 & 95.5 & 0.96 & 95.8 & 99.3 & 102.8 & 1.78 & \\
\hline $\begin{array}{l}\text { 1000-grain weight on } \\
\text { main shoot, g }\end{array}$ & 28.9 & 28.1 & 22.0 & 16.1 & $5.95^{* * *}$ & 29.2 & 25.3 & 16.8 & $8.93^{* * *}$ & \\
\hline $\begin{array}{l}\text { 1000-grain weight on } \\
\text { secondary shoot, g }\end{array}$ & 9.4 & 4.0 & 2.9 & 2.9 & $4.83 * *$ & 7.1 & 3.6 & 3.7 & 2.55 & \\
\hline
\end{tabular}

ages a plant in two ways. It draws nourishment out of the plant and simultaneously injects into it saliva which helps to digest the food and injurious to the plant. The combined effect of these measures is less with nymphs than with adults, and with male than with female adults. This may be due to the fact that females start laying eggs approximately 1-5 days after emergence and the number of eggs is greater than that of other planthoppers studied (RAATIKAINEN and VASARAINEN 1990). Females thus need more food than males and so cause more injury to the plant than either males or nymphs.

There is great variation in the abundance of $M$. propinqua and, from time to time, it may cause a significant decrease in the yield of grasses. 


\title{
References
}

Bremer, K. \& RaAtikainen, M. 1975. Cereal diseases transmitted or caused by aphids and leafhoppers in Turkey. Annales Academiae Scientiarum Fennicae Series A, IV Biologica 203: 1-14.

DLABOLA, J. 1957. Results of the zoological expedition of the National Museum in Prague to Turkey. 20. Homoptera, Auchenorrhyncha. - Acta Entomologica Musei Nationalis Prague 31, 469: 19-68.
Metcalf, Z.P. 1943. General catalogue of the Hemiptera IV, Fulgoroidea. 3, Araeopidae (Delphacidae). - Northampton, Mass. U.S.A. 552 p.

RaAtikainen, M. \& VASARAinen, A. 1990. Biology of Metadelphax propinqua (Fieber) (Homoptera, Delphacidae). - Entomologica Fennica 1: 145-149.

Manuscript received April 1993

\section{SELOSTUS}

\section{Metadelphax propinqua -kaskaan imennän vaikutus ohraan}

\author{
Mikko RaAtikainen, Terttu RaAtikainen ja Arja Vasarainen
}

Jyväskylän yliopisto ja Maatalouden tutkimuskeskus

\begin{abstract}
Metadelphax propinqua -kaskaan imennän aiheuttamia vioituksia ohralle tutkittiin 1970-luvun alussa. Kokeissa M. propinqua -lajin toukkia, koiraita ja naaraita laitettiin $0,1,2$ ja 4 kappaletta ohrille neljäksi, kahdeksaksi ja kuudeksitoista vuorokaudeksi. Kokeessa olleen ohran lajike oli Tammi.

Toukkien imennän vaikutuksesta ohran kuivapaino, jyvien paino ja pääverson 1000 -jyvän paino jäivăt văhän pienemmiksi kuin terveiden ohrien.

Koiraiden imennän vaikutuksesta ohran pituus, kuivapaino, jyvämäärä ja jyväsato jäivät pienemmiksi kuin terveiden ohrien.
\end{abstract}

Naaraiden imennän vaikutuksesta melkein kaikki tutkitut ominaisuudet jäivăt paljon pienemmiksi kuin terveiden ohrien. Naaraat olivat ohran pahoja tuholaisia, jos niitä oli paljon ja ne päăsivăt ohriin kasvin ollessa pienină oraina. Vioitus aiheutunee kaskaan kasviin laskemasta syljestä ja kasvista ottamasta ravinnosta. Viimeksi mainittu lienee pääsyy, sillä naaras alkaa munia 1-5 vuorokautta aikuistumisen jälkeen ja ottaa siitä alkaen usean viikon aikana paljon ravintoa ohrista. 